\title{
Polymer wastes and management in cities and towns of Africa and sustainable environment: Nigeria and European experiences
}

\author{
Kofo Ade Aderogba \\ Department of Geography \& Environmental Management Tai Solarin University of Education, Ijebu-Ode, Nigeria \\ Email address: \\ kofoaderogba@yaho.com \\ To cite this article: \\ Kofo Ade Aderogba. Polymer Wastes and Management in Cities and Towns of Africa and Sustainable Environment: Nigeria and \\ European Experiences. Social Sciences. Special Issue: Geographical evidence in changing Europe. Vol. 3, No. 4-1, 2014 , pp. 79-88. \\ doi: $10.11648 /$ j.ss.s.2014030401.19
}

\begin{abstract}
Polymer wastes litter everywhere. The objective of the paper is to assess the quantity and effects in the cities and towns with a view to make suggestions for globule in the risks of resultant environmental degradation for sustainable environment. The plants and facilities for manufacturing were visited. 9 Research Assistants were used for data and information collection. Market women and dealers were forth coming in the quantity sold per month/year; wastes generated; challenges and means of eluding the challenges. Directors, Environment in the States visited also gave information on the enormity of plastic wastes and their impact. They offered suggestion for sustainable environment. A dump each in 30 Nigerian cities and towns were studied for ten years, 2003 - 2012. Composition, quantity and spread of plastic wastes were examined. Literature on plastic wastes and management in European countries were read. Impacts were studied and compared with European cities. 80 photographic snaps were taken of polymer wastes and sceneries of visible consequences. Maps, graphs, charts, tables and percentiles were used for data analysis and presentation. Averagely, polymer wastes constitute $28.00 \%$ of the wastes found at dumps and around streets, residential, recreational and other public places. The concentrations are highest at recreation and residential areas. They are non-degradable; and every moment, there are additions. On the average, less than $12 \%$ are recycled annually. The recycling is not absolute. A time will come when there may be no substratum for plant growth. They are hide-outs and breeding grounds for disease vectors, animals and insects; and even, hoodlums; it destroys the aesthetic value of the physical environment: atmosphere, water bodies and soil. There are neither special technologies nor policies and programmes for special collection, transportation and disposal as obtained in most of the European cities and towns. Government may have to borrow leaves from Europe and invest massively on research and development and campaign for reducing, reusing and recycling the polymer wastes. Respecting the urban physical environment for sustainable development in Nigeria and generally in Africa is recommended.
\end{abstract}

Keywords: Polymer Wastes, Cities, Africa, Sustainable Environment, Research and Development

\section{Introduction}

There are wastes in various forms and types and the existence, management and challenges in human settlements have been of concern to individuals, communities, governments, organizations, research and development (Rochman, Hoh, Kurobe \& Teh, 2013; Klika, 2013; Hamer, 2003, Bath, 2012, Evans \& Bishop, 2000; William, 2002 and Zaini, 2011). There are degradable and non-degradable wastes; solid, liquid, gaseous and radioactive wastes; animal and plant wastes, domestic, industrial, hospital, commercial, agricultural, celebrations, decorations and others, (Walling, Walston, Warren, Warshay \& Wilhelm, 2004; Zaini, 2011; Hamer, 2003 Rochman, 2013; Klika, 2013; and Aderogba, In Print). It may be elegant to define waste as leftovers, excesses, surpluses, unwanted and remains that are discarded, castoff, rejected, superfluous, dumped and or thrown away. But one thing is unique to all: they are unwanted materials, at a moment in time, which resulted from processes of production and or transformation of some material resources to another. Though, there are some schools of thought that believe that there is no material entity that is absolutely a waste. In this respect, it means such materials are only awaiting more purposeful uses and or there are no 
yet technologies of developing them into useful states and or entity, (Aderogba, In Print and Chen and Patel, 2012). In this instance therefore, used tyres may not be regarded as waste. In other words, wastes are the remnants of productions, processing, non-serviceability, disuse and others that have been discarded and abandoned for wants of immediate use.

Many scholars have worked and defined what constitutes wastes in human settlements, and in particular, the challenges posed in human settlements for sustainable development, (Bath, 2012, Evans \& Bishop, 2000 and Weber, Gaius, Tyskling, Johnston, et al, 2008). Locally in Nigeria and for Nigerian cities and towns, Aderogba (2012), Aderogba \& Afelumo (2012), Agwamba, (1998), Akanmu, (2000), Ogwueleke, (2006) and Onibokun, Adedipe \& Sridlier (2000) have recognized and differently worked on the challenges of solid wastes in Nigeria; and Africa generally. It is in the light of these that, Onibokun et al (2000) dwell on The Challenges of Wastes in Nigeria and Africa with particular emphasis on Affordable Technologies and Strategies. But, works on plastic wastes in Nigerian cities and towns are limited, (Aguwamba, 1998; Imam, Wilson and Cheeseman, 2008; and Aderogba, In Print). Only similar to it is the submit held in Lagos and hosted by the Lagos State Environmental Protection Agency in 2011 on Regulation and Management of e-wastes in Nigeria. It was first of its type in Nigeria and probably in Africa, yet it does not address the issues of plastic/polymer wastes directly as it has been severally and meticulously addressed for the cities and towns of Europe (William, 2002; European Commission, 2009; Chertow, 2000 and Unite Nations, 2012). Emphasizes are on e-wastes.

There is virtually no where plastics as mold, extrusions, grains and films are not used in reasonable quantities - in laboratories, homes, industries, schools and colleges, tourist centers and others, (Ogwueleke, 2006 and Klika, 2013). A freelance writer once remarks:

\begin{abstract}
Plastic is found in virtually everything these days. Your food and hygiene products are packaged in it. Your car, phone and computer are made from it. And you might even chew on it daily in the form of gum. While most plastics are touted as recyclable, the reality is that they're "down cycled." A plastic milk carton can never be recycled into another carton - it can be made into a lower-quality item like plastic lumber, which can't be recycled.
\end{abstract}

Beth, S. (2012)

How big is the plastic problem, therefore? The challenge is not peculiar to Nigeria and Africa, (Weber, et al, 2008). According to them, of the 30 million tons of plastic waste generated in the U.S. in 2009 , only $7 \%$ was recovered for recycling. This plastic wastes end up in landfills, beaches, rivers and oceans and contributes to such devastating problems as the Great Pacific Ocean Garbage Patch, a swirling vortex of garbage, the size of a continent where plastic outnumbers plankton, assert Weber et al (2008). Similarly, UK uses; and generates over 5billions of plastic waste every year (European Commission, 2009)

The purpose of this work is to study the enormity of plastic wastes in African cities and towns; and its implications for sustainable environments in the urbanized settlements using Nigeria as a case study; and comparison made with European Countries. The work is limited to polymer wastes that are no longer in custody of the generators, abandoned and no immediate use can be found of them. These are those at public bins, dumps; and 'wondering' around compounds, residential buildings, public places and others. Detailed Chemistry of polymers in production and management of its wastes are beyond the scope of this work. Selected cities and towns of Nigeria are used as case study. The usefulness of plastic wastes is not significantly discussed.

\section{Concepts of Polymer, Plastics and Wastes}

The word Polymer is derived from the Greek words 'poly' meaning many and 'meros' meaning part. They often then infer that this term applies to giant molecule built up of large number of interconnected monomer units. The concept of polymerization was originally applied to the situation in which molecules had identical empirical formula but very different chemical and physical properties. Examples are benzene and acetylene. However, there are a number of methods of classification: One is to adopt the approach of using their response to thermal treatment and to divide them into thermoplastics and thermosets. Another is based on the nature of the chemical reaction employed in the polimerisation. Here, the two major groups are the condensation and addition polymers. There can be further classification and modification whereby reclassified polymerization as step reaction or chain reactions corresponding approximately to condensation or addition. But structures and properties of polymers has severally resulted in the common ply (ethylene - which may result from either High Pressure Processes, Ziegler Processes, The Phillips Process, or The Standard Oil [Indiana] Process), Poly (propylene), Poly (methyl methacrylate), Poly (styrene), Poly (vinyl chloride, PVC, Nylon, Expoxy Resins, Phenol-Formaldehyde Polymers, Amino Resins Poly (tetrafluoroethylene) PTFE, Polymethanes, Poly (ether ketone), silicones, Naturally occurring Polymers, Cellulose, starch, Natural Rubber, Protein, and Poly(3-hydroxybutynate).

But basically, Saunder, (1998) asserts that a polymer is a large molecule built up from numerous smaller molecules. These large molecules may be linear, slightly branched, or highly interconnected. In the latter case, the structure develops into a large three-dimensional network. The smaller molecules used as basic building blocks for these large molecules are known as monomers. A good example is the commercially important material poly (vinyl chloride) made from the monomer vinyl Chloride (Nicholson, 2011). 
The repeat units in the polymer usually correspond to the monomer from which the polymer was made. There are exceptions to this, though. Poly (vinyl alcohol) is formerly considered to be made up of vinyl alcohol $\left(\mathrm{CH}_{2} \mathrm{CHOH}\right)$ repeat units but there is , in fact, no such monomer as vinyl alcohol. The appropriate molecular unit exists in the alternative tautomeric form, ethanol $\mathrm{CH}_{3} \mathrm{CHO}$. To arrive at this polymer, it is necessary first to prepare poly (vinl ethanoate) from the monomer vinyl ethanoate, and then to hydrolyse the product to yield the polymeric alcohol.

The size may be defined either by mass or by number of repeat units in the molecule. It is this later indicator of size that is called the Degree of Poly merisation (DP). The relative molar mass of the polymer is thus the product of the relative molar mass of the repeat unit and the DP. There is no clear cut bound between Polymer Chemistry and the rest of Chemistry. As a very rough guide, molecules of relative molar mass of at least 1000 or a DP of 100 are considered to fall into the domain of Polymer Chemistry (Al-Keem, 2006).

The vast majority in commercial use is organic in nature, that is, they are based on covalent compounds of carbon. This is also true of the Silicones which, though based on Silicone-Oxygen backbones, also generally contain significant proportions of hydrocarbon groups. The other elements involved in Polymer Chemistry mostly commonly include hydrogen, Oxygen, Chlorine, Fluorine, Phosphorous and Sulphur, that is, those elements which are able to form covalent bounds albeit of some polarity with carbon.

As it is the characteristics of covalent compounds, in addition to primary covalent forces, polymer molecules are also subjects to various secondary intermolecular forces. This include dipole forces between oppositely charged ends of polar bounds and dispassion forces which arise due to perturbation of electron clouds about individual atoms within the polymer molecules. Hydrogen bonding which arises from the particularly intense dipoles associated with hydrogen atoms attached to electro-negative elements such as oxygen on nitrogen, is important in certain polymer notably proteins. Hydrogen bonds have the effects of fixing the molecules in a particular orientation, (Chen and Patel, 2012); and according to them, these fixed structures are essential for the specific functions that protein have in the biochemical processes of life.

However, it is critical to know that plastic is synthetic, moldable materials made of a chemical compound or 'polymer' that consists primarily of carbon atoms derived primarily from petroleum (petrochemicals) and generally from polymers. Common uses for the plastics include textiles, food packaging, bottles, shower curtains, plumbing pipes, furniture, flooring, eyeglasses, and coatings. Most plastics contain other organic or inorganic compound additives. Many of the controversies associated with plastics surround additives (such as BPA); biodegradability; post-consumer waste; and the use of oil in manufacturing, production and transportation.
The production and use of bioplastics is generally regarded as a more sustainable activity when compared with plastic production from petroleum (petroplastic), because it relies less on fossil fuel as a carbon source and also introduces fewer, net-new greenhouse emissions if it biodegrades. They significantly reduce hazardous waste caused by oil-derived plastics, which remain solid for hundreds of years, and open a new era in packing technology and industry (Nicholson, 2012).

Irrespective of the structure, uses and others, plastics/polymers are commonly found everywhere, anywhere; and put to use in day to day activities of man. No wonder, the increasing number of petrochemical plants around the globe, (Hong, Peter, Yu \& Chee, 1999 and Roy, Rollin \& Schreiber, 2004). The duration of its particular usage differ significantly based on several parameters but it is consequently 'discarded' as unwanted and thus become part of wastes in any locality its usefulness is last appreciated either in its original form and or as it might have been modified.

\section{Materials and Methods}

Nigeria is a republic on the Gulf of Guinea in West Africa. She is defined by Latitude $4^{\mathrm{O}}$ and $14^{\mathrm{O}}$ North and Longitude $3^{\mathrm{O}}$ and $14^{\mathrm{O}}$ East coordinates; and with total land area of about $923,773 \mathrm{~km}^{2}$ (that is, $356.669 \mathrm{ml}^{2}$ ). It is about $910,768 \mathrm{~km}^{2}$ of land and $13,004 \mathrm{~km}^{2}$ of water. She is sharing boundaries with Democratic Republic of Cameron $(1,690 \mathrm{~km})$, Benin Republic $(773 \mathrm{~km})$ and the Niger Republic $(1,497 \mathrm{~km})$ in the east, west and north respectively. The southern boundary is the Bight of Benin $(853 \mathrm{~km})$; and Lake Chad and Chad Republic $(87 \mathrm{~km})$ are to the north east. See Figure 1: a) Nigeria Satellite imagery; b) relief and drainage; c) vegetation, major cities and towns; and d) Population Density. It is a region of contrast: the soil; relief and drainage; climate and vegetation; density, structure and composition of population; ethnicity; economy and agricultural types and productions; culture and religious beliefs; foods and drinks; industrialization, productions; and others.

The terrain varies from coastal swamps and tropical forest in the south, to savannah and semi desert in the north. Approximately $33 \%\left(300,550 \mathrm{~km}^{2}\right)$ is under arable while $3.1 \%\left(28,234 \mathrm{~km}^{2}\right)$ is under permanent crops, $44 \%$ is under permanent pasture; and wood is $12 \%$, (Central Intelligence Agency (CIA), 2009). The highest points are the Jos Plateau $(1,200-2,000 \mathrm{~m}$ above sea level) and those at the eastern border, the Adamawa highlands. River Niger (the third longest river in Africa) forms a confluence with river Benue at Lokoja and reaches the sea through a massive delta of mangrove swamp, see Figures 1 (b) and (c).

The government is democratic with strong diplomatic and trade relations with United States of America, United Kingdom, South Africa, Germany, Canada, India, and a number of other African and Eurasian nations. Over $86 \%$ of the nation's economy; and over $85 \%$ of the population 
depend and engage in Agriculture until the 1970s when petroleum boom replaced the sector. Today, the economy is over $95 \%$ dependent on petroleum. The main export is petroleum. Obioh and Fagbenle (2008) assert that over 80\% of the population depends largely on biomass-based fuels which calculate out to be 0.5 metric tons of fuel wood per capital. As a result, the rate of deforestation is very high. According to them, "deforestation rate is estimated at approximately 350kha per year and is one of the key drivers of increasing desertification." Other environmental deforestation issues, such as erosion, flooding, drought and others are also increasing. The degradation together with other anthropogenic activities, have contributed to increasing rate of loss of biodiversity, (Fagbenle \& Kaneyiannis, 1994 and Obioh \& Fagbenle, 2008).

Apart from the state capitals that are characteristically urbanized, many cities and towns have long history of urban attributes as historical, cultural, educational, tourist, commercial and administrative centers; namely, Sokoto, Kano and Zaria in the North West; Maiduguri, Yola and Jos in the North East; Abuja, Ilorin, Makurdi and Lokoja in the Middle Belt; Ogbomosho, Oshogbo, Oyo, Ibadan, Abeokuta, Ile-Ife and Lagos in the South West; Benin, Warri and Port-Harcourt in the South South; and Onitsha, Owerri, Enugu, Aba and Calabar in the South East. Ubanisation is highest in the South West but population density is highest in the South East. See Figure 1 (d). Exception to this is Lagos that has over 2000 persons per $\mathrm{km}^{2}$ (Central Intelligence Agency, 2009).

(a)

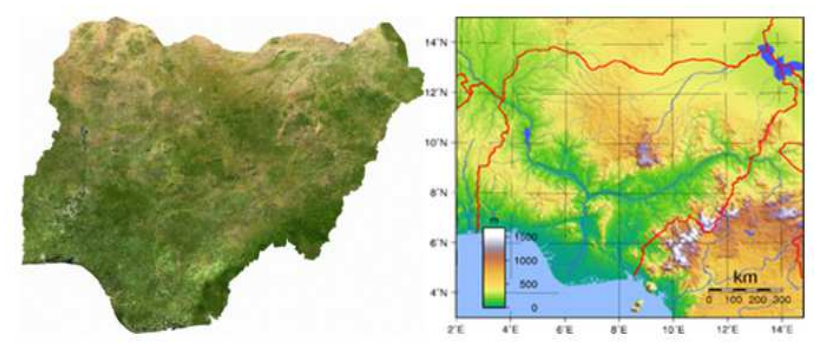

(c)

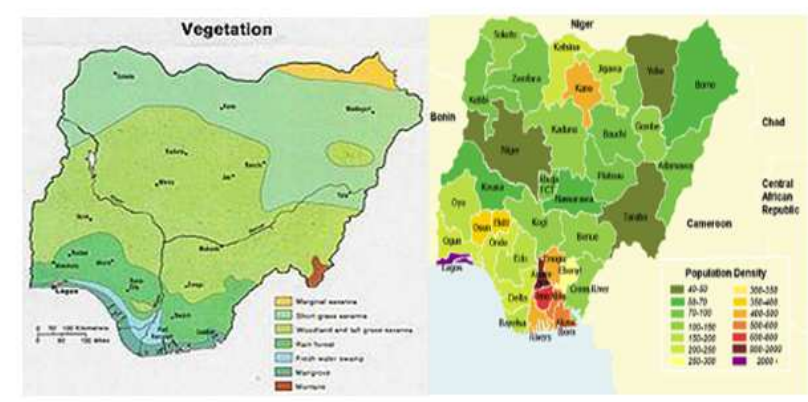

Fig 1. Nigeria: a) From Satelite Imagry; b) Releif and Drainage; c) Seven Major Vegetaion Belts, Cities and Towns; and (d) Population Density

There are three petrochemical plants, namely Kaduna Refinery and Petrochemicals Company Limited, Warri
Refinery and Petrochemicals Company Limited and Eleme Petrochemicals Company Limited at Kaduna, Warri and Port-Harcourt respectively. Eleme Petrochemicals Company Limited is producing at full $(100.00 \%)$ installed capacity but both Warri and Kaduna plants are epileptic in production capacities. The three plants are designed to produce various grades of resins/pellets of polypropylene, polyethylene, carbon black and others for local and international markets. Nigeria has local plants and facilities for moulding, extrusion, films and others. It is of interest to note that the quantity produced locally cannot meet local demands, (Shinsato, 2005) thus, there is massive importation of resins/pellets as feedstock for the local markets.

9 compensated Research Assistants were engaged for data collection across the country. South West and South East zones had 2 each while others had 1 each. See Table 1. The plants and facilities for moulding, extrusion, films and others were visited to ascertain their outputs in the 7 geographical zones of the country: North West, North Central, North East, Middle Belt, South West, South-South and South East. Each of the plants visited gave output of their plants per annum; and offered suggestion towards sustainable use of plastic products that guarantee sustainable environment. A market each was also visited in each of the geopolitical zones to be able to estimate the quantity of polymer products in the market at a time. Market women and dealers were all forth coming in the quantity sold per month/year; plastic wastes generated, challenges and means of eluding and or dealing with the challenges. 50 urbanites randomly selected among industrial, household, institutional and public sectors were interviewed on plastic wastes and its significance. Table 1 shows the distribution of selected cities, the interviewees and the studied dumps by geographic zones.

Table 1. Distribution of selected cities, Research Assistants, interviewees and studied dumps by geographic zones

\begin{tabular}{lllll}
\hline $\begin{array}{l}\text { Geographic } \\
\text { Zones }\end{array}$ & $\begin{array}{l}\text { No of } \\
\text { Cities }\end{array}$ & $\begin{array}{l}\text { No of } \\
\text { Research } \\
\text { Assistants }\end{array}$ & $\begin{array}{l}\text { No of } \\
\text { Interviewees }\end{array}$ & $\begin{array}{l}\text { No of } \\
\text { Studied } \\
\text { Dumps }\end{array}$ \\
\hline North West & 3 & 1 & 5 & 6 \\
North East & 4 & 1 & 6 & 8 \\
North Central & 4 & 1 & 6 & 8 \\
Middle Belt & 3 & 1 & 5 & 6 \\
South West & 7 & 2 & 13 & 14 \\
South South & 3 & 1 & 5 & 6 \\
South East & 6 & 2 & 10 & 12 \\
Total & 30 & 9 & 50 & 60 \\
\hline
\end{tabular}

Number of selected cities, interviewees and dumps studied are highest in South West, 7, 118 and 14 
respectively. This is followed closely by the South East with the figures 6,100 and 12 respectively. North West, Middle Belt and South South had the least figures each -3 , 5 and 6 respectively. See Table 1 . The differences were informed by the spatial differences in total population and densities between the zones (Mabogunje, 1968 and National Population Commission, 2006). Directors (Environment) in the States visited also gave information on the enormity of plastic wastes, their impact on the urban environment and offered suggestions for reducing the risks of environmental degradation particularly in the face of global warming. Similarly, concentrations of plastic wastes at 2 dumps each in 30 Nigerian cities and towns were studied. Composition, quantity and spread were studied. Impact on man and animals and sustainable environment were studied; and risks of continuous massive use were noted. The words polymer and plastics are used interchangeably to mean derived products of polymerization and other non-degradable polymer products. Emphasis is on non-degradable polymer/plastic products and the cities and towns of Nigeria.

\section{Findings}

Plastic products are produced in all the geographic zones and the product are found in virtually everything; and everywhere. The used and abandoned wastes are equally common. It is common scenery. Figures 2 and 3 show the commonly found plastic wastes at the dumps and around the cities and towns. They are of the forms of films, molds, extrusions and resins/pellets - ranging from electronics, automobiles, and home utensils to equipment, clothing, wares, accessories and mere pellets/resins. "Unless one has pinaciphobia, the fear of lists of what are available at any site contains just about everything to suit 'listicle' needs," remarked Aderogba \& Afelumo (2012). They are in various colours, shapes, sizes and forms. See Figure 2. Basically, they are starch-based, cellulose based, aliphatic polyester, poly lactic acid (PLA), poly-3-hydroxybutyrate (PHB), poly-hdroxyalkanoate (PHA), polyamide 11 (PA 11), bio-derived polyethylene, genetically modified bioplastic base and others, see Figures 2 and 3; and non-degradable (Hahamed, 2011 and Chen \& Patel, 2012).

The sources are local manufacturing plants and facilities, $18.45 \% ; 37.60 \%$ are imported manufactured plastics and other goods; $40.75 \%$ are wastes of fairly used imported goods, tools, equipment, and appliances, home and industrial wares, containers, packages, electronics and so on. Others (3.20\%) are unclassified. See Fig. 4. (a)

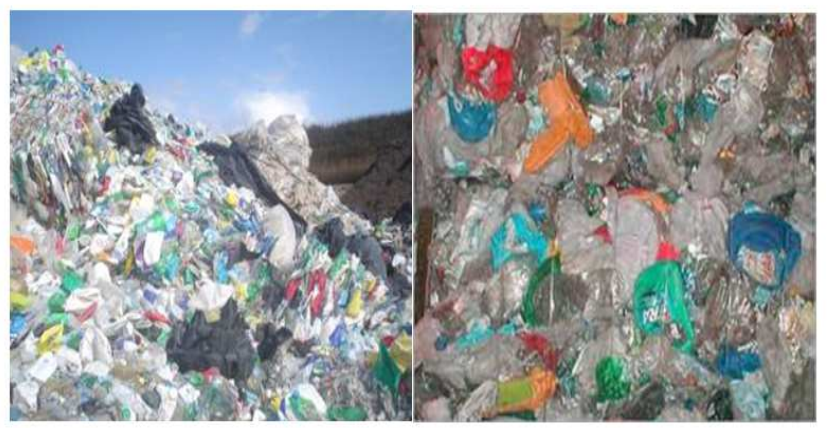

(c)

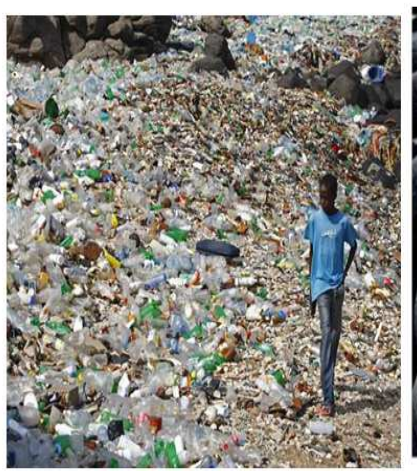

(e)

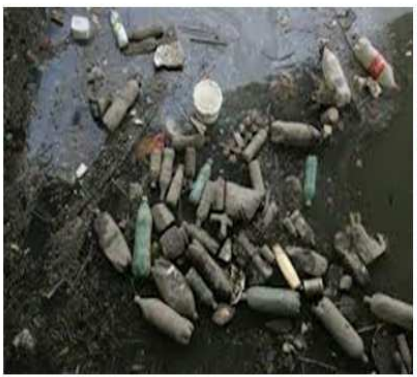

(g)

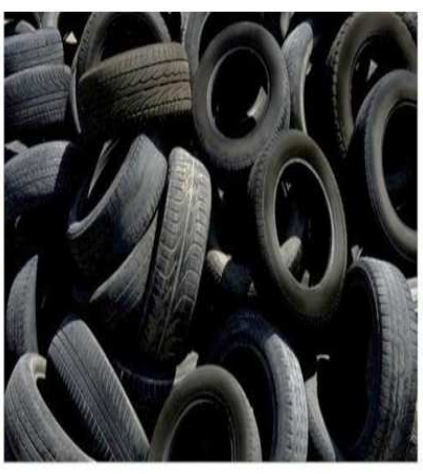

(f)

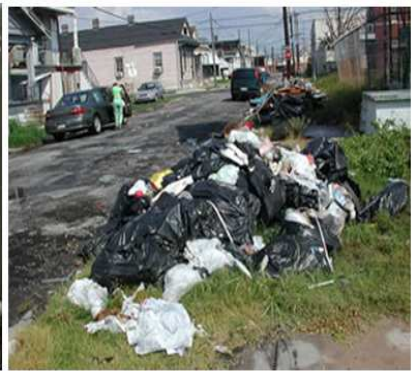

(h)

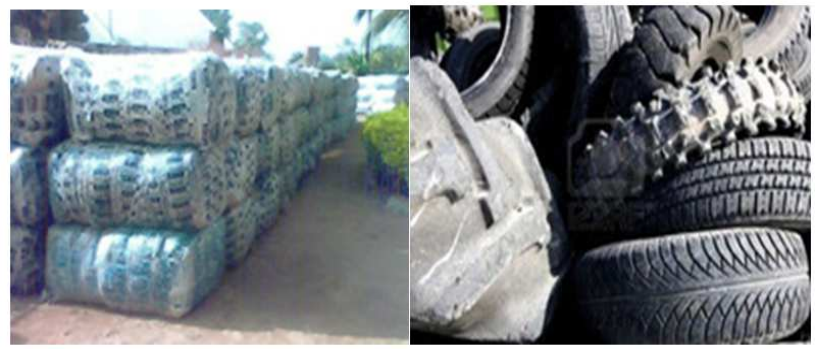

Figure 2: Heap of Plastics of various grades at Onitsha, home for lizard (Agama Agama) and other reptiles; b) Various film grades of Polymer at Abuja; c) Plastic Products and a scavenger at Gombe; and d) Heap of used tires, for sale, in Lagos; e) Thick Layer of Plastic Bottles, Cans and Sachets at Maiduguri; f) Plastic/cellophane sheets and wrappers in Kawo, Kaduna; g) Load of Plastic wastes (rappers/sheet and sachets) for sale at Aba; and h) Used tyres and tubes displayed for sale in Port-Harcourt. 


\begin{tabular}{|c|c|}
\hline Cellophane papers/bags & Computer casings and spares \\
\hline Telephone handsets & Water tanks and jerry cans \\
\hline $\begin{array}{l}\text { Photographic and Video } \\
\text { Cameras }\end{array}$ & Oil tanks and jerry cans \\
\hline Cutlass/hatchet/knife handles & Injection syringes \\
\hline Carrier bags & Lines and twins \\
\hline Plastic Chair and Table covers & Cellophane tapes and plasters \\
\hline Car covers & Foot mat, praying mats and sleep mats \\
\hline Plastic plates and dishes & Food and drug containers \\
\hline Plastic cups and mugs & Waste bins and baskets \\
\hline Plastic bottles and cans & Electrical generators and accessories \\
\hline Bottle openers & Doors and accessories \\
\hline $\begin{array}{l}\text { Binding rings and binding } \\
\text { films }\end{array}$ & Windows and accessories \\
\hline Bottle corks and covers & Paints and finishing \\
\hline Tooth brushes & Curtains and blinds \\
\hline Automobile (spare) parts & Electronics and accessories \\
\hline Toys & Gas cooker Accessories \\
\hline Plastic brooms and parker & Pressing Iron \\
\hline Foot wears & Ironing board \\
\hline Foot mats & Dusters and Napkins \\
\hline Plastic foams and bed sheets & Writing biros and pens \\
\hline Clothing & Crayon and paints \\
\hline Hose & Light and lamp accessories \\
\hline Electrical cable coatings & Blenders and cookers \\
\hline Roofing sheets & Envelops and folders \\
\hline $\begin{array}{l}\text { Plastic pales/buckets and } \\
\text { kettles }\end{array}$ & Table and tea spoons \\
\hline PVC Pressure pipes & Hampers wastes \\
\hline PVC Waste pipes & Baskets \\
\hline Tires and tubes & Sports and Games tools \\
\hline Ropes and twins & Shoe Brushes \\
\hline Clothes hangers, clips and pegs & Tables and Chairs \\
\hline Plastic Cartons & Flowers \\
\hline Nets & Flower verses \\
\hline Tool Boxes & Maps/globe and stands \\
\hline Bread and other food covers & Fans and accessories \\
\hline Pure Water Sachet & Water Bottle \\
\hline Lamps and lamp holders & Underwear (pant, breccia, singlet, etc) \\
\hline Chewing gum & Glasses frames \\
\hline $\begin{array}{l}\text { Electrical Plugs, sockets and } \\
\text { adaptors }\end{array}$ & Mirror frames \\
\hline Rosary and beads & Handles of cooking utensils \\
\hline Rings and Bracelets & Combs \\
\hline Mopping sticks and pestles & Tooth picks \\
\hline Watering cans & Sugar containers \\
\hline Costumes and regalia & Salt containers \\
\hline Clothes, shoe and cutlery racks & Pepper containers \\
\hline Artificial nails and hair & Dispensing bags \\
\hline Brief cases, bags and boxes & Caps and hats \\
\hline Wrappers and labels & Air conditioner accessories \\
\hline Scissors and tool handles & Egg and drink crates \\
\hline Decorations & Water Bottles \\
\hline Pure water sachets & Photographic frames \\
\hline Bed and Chair foams & Others \\
\hline
\end{tabular}

Figure 3: Polymer Wastes commonly found at Dump sites in the selected cities and towns

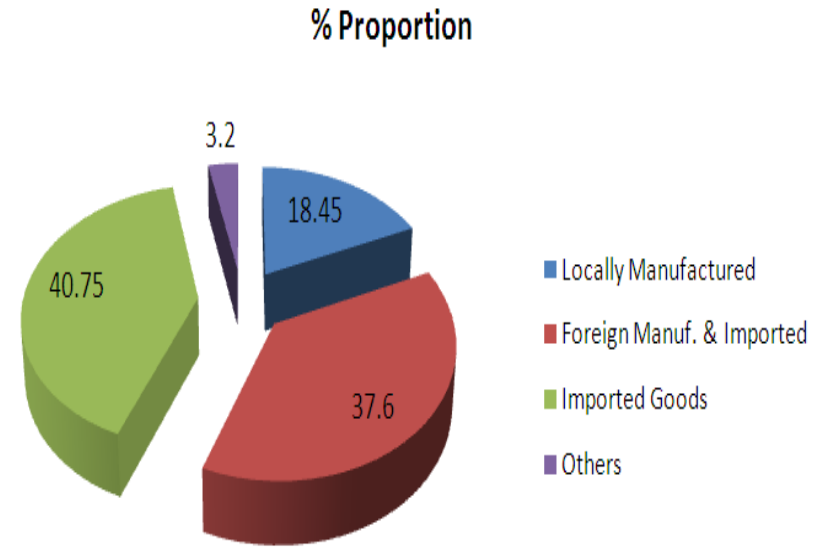

Figure: 4: Origin of Plastic Wastes found at the Dumps

A respondent has this to say in the course of an InDepth-Interview with him in Kano, one of the traditional and urbanized settlements:

I am with and around plastics throughout any day: from waking up from bed through brushing of teeth, bathing, breakfast, journey to the office, to work in the office, the tools and equipment used, recreation and relaxation after office, back to bed, the bed and beddings ....tooth brush, sponge, plates, cups, spoon, tables and chairs, car, television, radio, telephone, etc accessories and others. .......common scenery at a distance of any dump, among others, are black and dirty looking snow white of cellophane bags with dots of yellow, red, pink and blue. .... water sachets, water bottles .... Some had been there for over ten years or as old as the dump site, while additions are coming in every day. They are visibly non-degradable.

Fig. 5 shows the estimated quantity in $\mathrm{kg}$ over a period of 10 years. It was $138 \mathrm{~kg}$ in 2001 and $32 \mathrm{~kg}$ was added; but only $14 \mathrm{~kg}$ was recycled. Five years after, 2005, the corresponding figures are $178 \mathrm{~kg}, 51 \mathrm{~kg}$ and $25 \mathrm{~kg}$ respectively and under eight years, in 2011, the figures have risen to $233 \mathrm{~kg}, 76 \mathrm{~kg}$ and $33 \mathrm{~kg}$ respectively. See Fig. 5 . It is projected that by 2015 and 2017 the figures could be $280 \mathrm{~kg}, 85 \mathrm{~kg}$ and $40 \mathrm{~kg}$; and $320 \mathrm{~kg}, 88 \mathrm{~kg}$ and $40 \mathrm{~kg}$ respectively. It has not shown any sign of decreasing any year.

The rate of recycling is not commensurate with the rates at which the wastes are being generated and deposited into the environment. Only $14 \mathrm{~kg}(14.24 \%)$ in 2001 and just $13.06 \%$ of $268 \mathrm{~kg}$ in 2013 were recycled. Relative proportion of the quantity that may be recycled may be decreasing over time. The proportion may increase from $13.06 \%$ of 2013 to a pick, $14.29 \%$, in 2015 but it may drop to $12.50 \%$ in 2017 , and less in the subsequent years. See Fig 6 . 
Existing Plastic Wastes by Category/Kg/year)

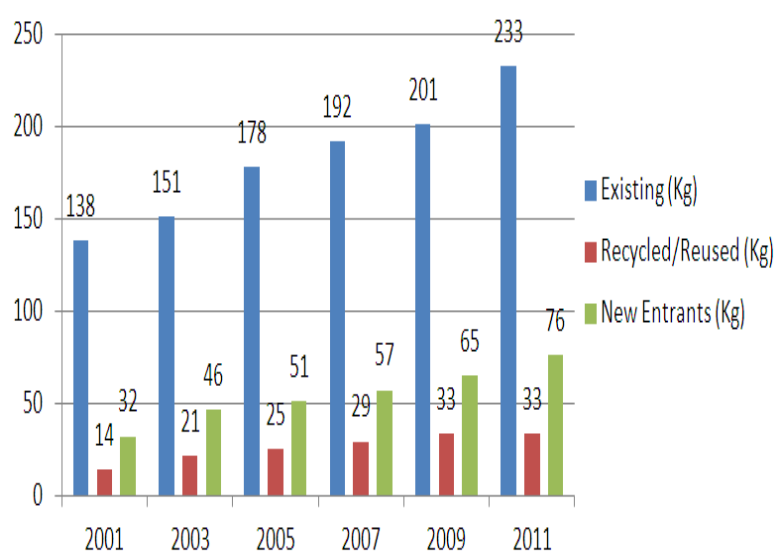

Years

Figure 5: Existing, Recycled and New Entrants of Plastic Wastes.

In European cities and towns, wastes generally are separated into cardboards/papers, glasses, plastics and general wastes, that is, towards effective waste management (British Plastic Federation, 2013). The policy and programme have ensured relatively clean environment devoid of plastic liters around residential, commercial, recreational and educational centers. Four plastic bins located at designated locations at public, residential, religious educational and other centers are compulsory for collection from source of the separated wastes. Asides, the bins are often emptied for onward disposal at regulated dumps at regular intervals. In addition, the dumps are meticulously managed. There are government policies and programmes that support and encourage these, (British Plastic Federation, 2013); and European Commission (2009) is of the view that the threat of global warm will require every approach to combat the effect of climate change and global warming.

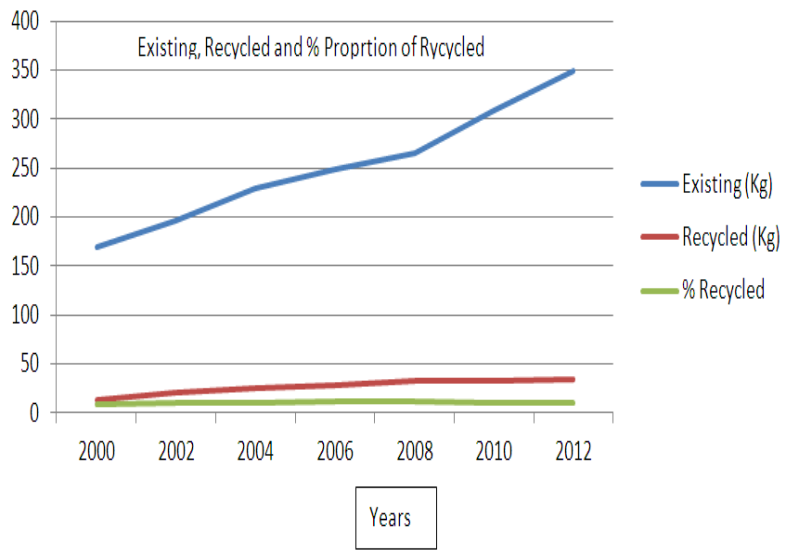

Figure 6: Comparison of Recycled to Existing Plastic Wastes (\%)

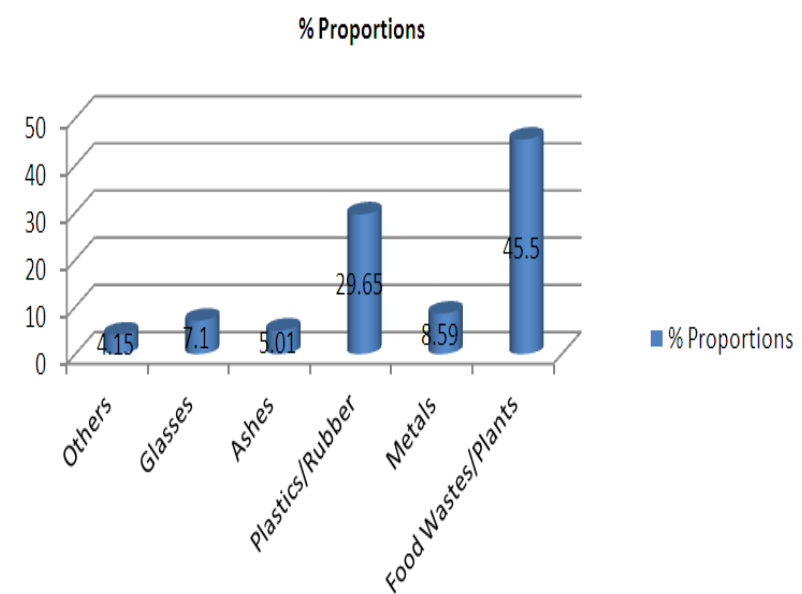

Figure 7: Proportion of Plastic/rubber wastes compared to others in a typical waste dump

Unlike in any European cities and towns, Figure 7 shows a comparison of wastes by categories in a typical waste dump in Lagos Metropolis, south western Nigeria. Ashes $(5.01 \%)$ are the lowest category followed by glasses $(7.10 \%)$, that is, apart from others $(4.15 \%)$. Plastic/rubber wastes are the highest, $(29.65 \% 0)$, that is, after food wastes and plant materials $(45.50 \%)$. In other words, the proportion of others, glasses, ashes and metals put together $(24.85 \%)$ is still less than the wastes due to plastic and rubber; see Figure 7 . This compared favorably with what was found at Enugu, Kano and Maiduguri; and even at the Federal Capital Territory, Abuja.

(a)

(b)

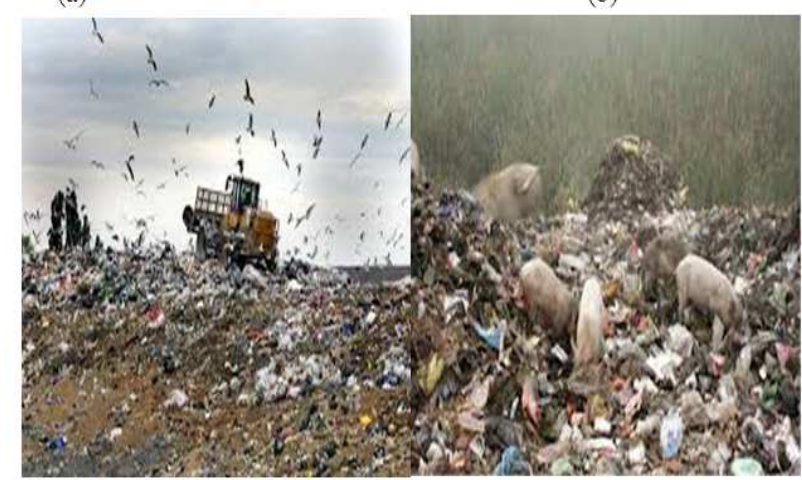

(c)

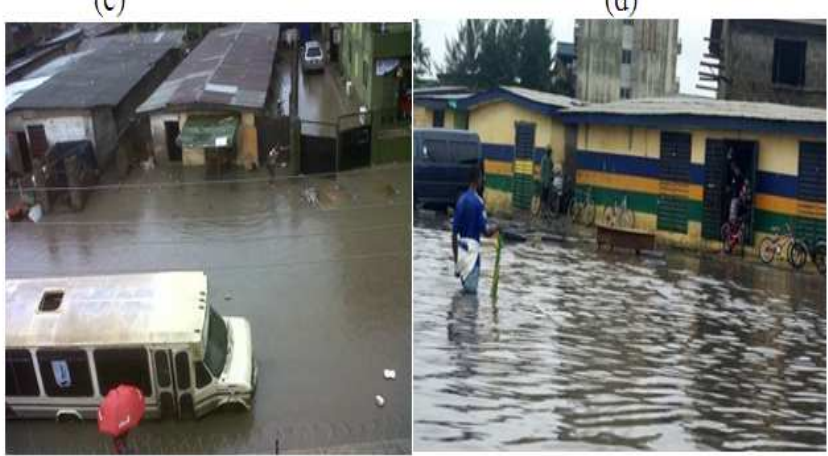


(e)

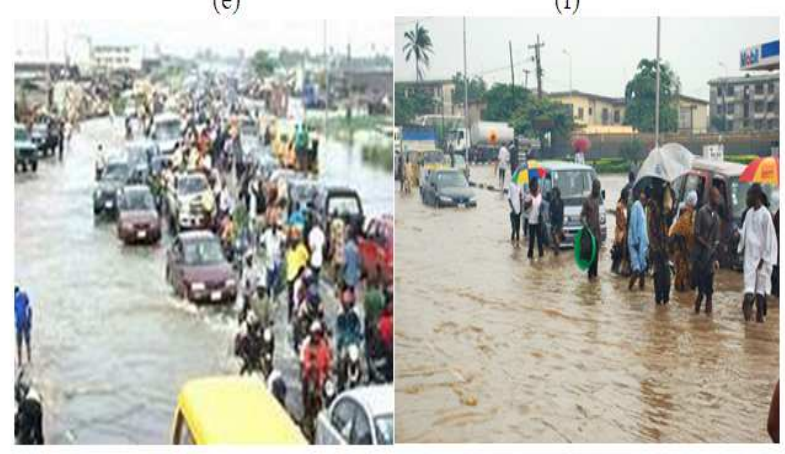

Figure 8: a) and b) mainly plastic/rubber wastes that aesthetically destroy the physical environment - air, water and land; c), d), e) and f) are massive floods that result from mainly plastic/rubber wastes on drainage channels.

The plastic wastes are not without some effects, positive and negative, on the environment. See Figure 8; and Table 2: consequences of plastic wastes in different parts of the cities and towns.

Including others (Specified), twelve (12) effects were adduced: See Table 2. Each respondent picked more than one effect/significance to the community. Only 36 (7.20\%) affirm that it is often reused/recycled to the advantage of the urbanites. 39 (7.80\%) said scavengers do pick them for reuse/sales/exchange for money. But all the respondents $500(100.00 \%)$ each time, affirm that they block drains and destroy the aesthetic value of the physical environment earth surface and soil, plants and flowers, the atmosphere and water. It prevents luxuriant growth of ornamental plants and arable crops, $71.00 \%$; it liters streets, roads and corridors of residential, public and industrial places, $70.14 \% .87 .40 \%$ (447) say it retains water; $75.40 \%$ opined that they are breeding ground for disease vectors and for mosquito larvae and others. Similarly, 497 (99.94\%) and $493(98.60 \%)$ respectively affirm that it blocks roads and pollute the environment (Water, soil, land and atmosphere). See Table 2.

Table 2: Effects of Polymer Wastes in the Urban Environment

\begin{tabular}{lll}
\hline Effects & $\begin{array}{l}\text { No of } \\
\text { Respondents }\end{array}$ & \% Proportion \\
\hline $\begin{array}{l}\text { Often Reused/Recycled } \\
\text { Prevents Luxuriant growth of } \\
\text { ornamental Plants }\end{array}$ & 36 & 7.20 \\
$\begin{array}{l}\text { Block Drains } \\
\text { Litter Streets }\end{array}$ & 500 & 71.00 \\
$\begin{array}{l}\text { Contains/retains water } \\
\text { Breeding ground for disease }\end{array}$ & 491 & 100.00 \\
$\begin{array}{l}\text { vectors } \\
\text { Breeding ground for mosquitos }\end{array}$ & 447 & 70.14 \\
$\begin{array}{l}\text { larvae \& others } \\
\text { Block roads }\end{array}$ & 387 & 89.40 \\
$\begin{array}{l}\text { Pollute environment (Water, Soil, } \\
\text { Land \& Air) }\end{array}$ & 497 & 75.00 \\
$\begin{array}{l}\text { Destroy aesthetic value of } \\
\text { flowers and the 'sky' }\end{array}$ & 500 & 75.40 \\
$\begin{array}{l}\text { Source of Income to Scavengers } \\
\text { Others (Specified) }\end{array}$ & 39 & 98.60 \\
\hline
\end{tabular}

It continues to increase in quantum and spread at the dumps and all around residential, recreational and tourist, industrial, commercial and institutional areas. Averagely, it constitutes about $17 \%$ of wastes (highest after vegetable and plant material) at dumps in 2003. The proportion increased to $19.85 \%$ in $2007 ; 21.38 \%$ in $2009 ; 25.55 \%$ in 2011; and about $30 \%$ at the last observations.

There are certain spatial differences depicted by the spread of these wastes: The quantity and density over space is higher at the dumps in high density residential areas such as Gbagada, Mushin and Ajegunle of Lagos (Nigeria). Conversely, sophistication is low in such high density residential areas. The films are easily carried away just as both films and empty bottles are easily swaggered by water runoffs to drainage channels to block the drains though the daily activities of scavengers do partially sort out selected useful few for reuse/recycle/sales.

In comparison with any of the cities and towns of Europe, there are no parameters that compare with those of Europe: quantity of plastic used and recycled; methods of management of the wastes generated; and the consequences on the environment (European Commission, 2009; Green Paper, 2007 and British Plastic Federation, 2013). All forms of wastes are separated at the generated points for ease of management and control. Papers are used more often than plastics. There are elaborate education and campaign for recycling of plastics and use of paper in place of plastics. Nearly all types of plastics can be recycled, (British Plastic Federation, 2013). Though, the extent to which they are recycled depends upon technical, economic and logistic factors, as a valuable and finite resource, the optimum recovery route for most plastic items at the "endof-life" is to be recycled, preferably back into product that can then be recycled again and again and so on. The UK uses 5 million tons of plastic each year of which an estimated $25 \%$ is currently been recovered or recycled (British Plastic Federation, 2013). The recycling fits into the waste framework hierarchy of efficient and sustainable use of material resource that often inculcates the hierarchy as now enshrined in the law as a result of the recently revised Waste Framework Directive (British Plastic Federation, 2013). These include the following:

1) Prevention: Using less material in design and manufacture. Keeping products for longer; re-use. (Using less hazardous material).

2) Preparing for re-use: Checking, cleaning, repairing, refurbishing, repair whole items or spare parts.

3) Recycling: Turning waste into a new substance or product. Includes composting if it meets quality protocols.

4) Other recovery including anaerobic digestion, incineration with energy recovery, gasification and pyrolysis which produce energy (fuels, heat and power) and materials from waste: some backfilling operations.

5) Disposal: Landfill and incineration without energy recovery. 
Following from the foregoing, the circumstances are way off in Nigeria. Less than $1 \%$ of the plastic wastes generated are recovered and emphasis and continuous use of plastic materials is getting exacerbated by the day. No significant effort by neither government nor organized groups or individuals has been in place. It is projected that these spates will continue to increase over time if there will be no check to the extent of high dependence and usage; and consequently management of resultant wastes. It is threat to sustainable physical environment in the cities and towns of Nigeria; and Africa.

\section{Discussion}

This work has established that plastic wastes constitute about $30 \%$ of wastes at dumps all over. The quantum and spread are increasing over the years at waste dumps; residential, industrial, commercial, recreational, transportation and other places around and within cities and towns. They are risks and challenges to sustainable urban physical environment: They are non-degradable; and there are no apposite technologies of adequately reusing and recycling. With time, the challenges may be compounded to the extent that there may not be suitable quantity of soil substratum for growth of ornamental and arable plants. Drainage channels would continue to be blocked and it may result in more devastating floods. It is carcinogenic. With the global warming, the emerging risks will turn to be disastrous to lives and development in human settlement.

Incidentally and conversely, the European nations, like most developed world are making frantic efforts in research, development, policies, programmes and practices to reduce the use of plastic materials, wastes generated and consequences on the physical environment. It may be impossible to put an end to continuous use of plastic and polymer products, but uncontrolled usage may have to be checked. Separation of wastes generally must now become compulsory at homes, offices, recreation centers, hospitals and maternity homes, schools and colleges, churches and mosques and others, that is, for ease of management.

\section{Conclusion}

Plastic wastes constitute major defies to sustainable physical development in the human settlements of Nigeria, that is, compared to those cities and towns of Europe. The challenges will be compounded if adequate measures are not put in place to reduce vulnerability particularly in the face of global warming and climate change. It is the opinion of this paper that governments may have to borrow leaves from European nations and invest massively on research and development; and campaign massively for reducing, reusing and recycling. It could be "re-melted", remolded and or extruded, injected and others. In all circumstances, the use of paper and degradable materials should be encouraged and supported. Governments and policy makers may have to direct and enforce plastic manufacturer to double their investments in such research and development; directly involve in picking/recovering plastic wastes in the communities for reuse and recycle. There must be polies and programmes for waste separation from source for ease of identification and management. These may not be out of ways. Above all, respecting the urban physical environment for sustainable development in Nigeria and generally in Africa is recommended. Inculcating sustainable waste management behaviour in urban dwellers is desirable; and therefore recommended. Campaigns, education and others in schools, colleges, and public places; radio, television, newspapers, magazines and periodicals will go a long way.

\section{References}

[1] Aderogba, K. A. 2011. Global Warming and Challenges of Floods in Lagos Metropolis Nigeria. Academic Research International Vol. 2 No. 1 pp. 418-468.

[2] Aderogba, K. A and Afelumo, A. A. 2012. Waste Dumps and Their Management in Lagos Metropolis. International Journal of Learning and Development Vol. 2 No. 1 pp. 1-16.

[3] Aderogba, K. A. In Print. Unsustainable E-Wastes Management Behaviour and Risks to Environmental Sustainability in Africa: A Glance at Nigeria. Department of Geography and Environmental Management. Tai Solarin University of Education, Ijebu-Ode, Nigeria.

[4] Agunwamba, J. C. 1998. "Solid Waste Management in Nigeria: Problems and Issues." Environmental Management. Vol. 22 No. 6 pp. 849 -56; (November).

[5] Akanmu, J. O. 2000: Integrated Waste Management: A Tool for Poverty Alleviation. Proceedings of the National Engineering Conference and Annual General Meeting on Engineering Strategies for Poverty Alleviation. Abuja, (20 24 November), pp. $43-50$.

[6] Al-Keem B. T. 2006: Use of Plastic Wastes in Blast Furnace. ENVIS Center on Management of Plastic, Polymer Wastes and Bio polymers. Mumbai: Indian Center for plastic in the environment. Vol. 4 Issue 4, (September).

[7] Beth, S. 2012: Simple Ways to Reuse and Recycle Your Holiday Décor. London: World Street Journal (Saturday, $28^{\text {th }}$ December).

[8] British Plastic Federation (2013): The UK's Leading Plastic Trade Association Report for 2013 Trade. London: British Plastic Federation

[9] Central Intelligence Agency. 2009: The 2008 World Factbook - Nigeria. Washington, DC: Central Intelligence Agency (CIA), United States of America.

[10] Chen, G., \& Patel, M. 2012: Plastics derived from biological sources: Present and future: P technical and environmental review. Chemical Reviews, Vol. 112 No. 4, pp. 2082-2099.

[11] Chertow M. (2000): Industrial symbiosis: Literature and taxonomy. Annu. Rev. Energy Environ., 25:313-337.

[12] European Commission (2009): White Paper on Climate Change - SEC 386,387,388. 
[13] Evans, D. and Bishop, I. 2000: Resource Conservation and Recycling. Oxford: Oxford University Press; pp. 32, $289-$ 313.

[14] Fagbenle, R. Layi and Kaneyiannis, T. G. 1994: On the Wind Energy Resources of Nigeria. International Journal of Energy Research. Vol. 18, pp. $493-508$.

[15] Green Paper (2007): Adapting to Climate Change in Europe- Option for EU Action, 2007.

[16] Hahamed, K. R. 2011: Plastic Waste Management Recycling and Recovery Options. ENVIS Center on Management of Plastic, Polymer Wastes and Bio polymers. Mumbai: Indian Center for plastic in the environment. Vol.12; Issue 3, (September).

[17] Hamer, G. 2003: Solid waste Treatment and Disposal: Effects on Public Health and Environmental Safety. Biotehno. Adv. Vol. 26 Nos. 2; pp. $195-205$.

[18] Hong, C., Peter H. F. Yu, and Chee, K. Ma (1999-03). "Accumulation of Biopolymers in Activated Sludge Biomass". Applied Biochemistry and Biotechnology (Humana Press Inc.) 78: 389-399.

[19] Imam, A. Mohamed, B. Wilson, D. C. \& Cheeseman, C. R. 2008: Solid Waste Management in Abuja, Nigeria. Waste Management. Vol. 28 No. 2; pp. 468 - 72 .

[20] Klika KD (2013): Waste Plastics and Pharmaceuticals, could an Integration Solution help? Environmental Science \& Technology. 47 (18): $10111-2$.

[21] Kyoto Protocol (1997): United Nations Framework Convention on Climate Change - UNFCCC, 1997 and its evolution to 2012 .

[22] Mabogunje, A. L. 1968. Urbanization in Nigeria. London: University of London Press; pp. 66 - 86.

[23] National Population Commission. 2006. Nigerian National Population Census Results. Abuja: National Population Commission.

[24] Nicholson, J. W. 2012: The Chemistry of Polymers. Cambridge: Royal Society of Chemistry. ( $4^{\text {th }}$ Edition); pp. $14-23$.

[25] Obioh, I. B. and Fagbenle, R. O. 2009: Energy Systems: Vulnerability-Adaptation-Resilience - Regional Focus on Sub-Saharan Africa: Nigeria. Paris: HELIO International/Nigeria.

[26] Ogbonna, D. N.; Ekweozor, I. K. E.; Igwe, F. U. 2002 "Waste Management: A Tool for Environmental Protection in Nigeria". A Journal of the Human Environment 31 (1): $55-57$.

[27] Ogwueleke, T. 2006: Municipal Solid Waste Characteristics and Management in Nigeria. Iran Journal of Environmental Health, Science and Engineering. Vol. 6, No. 3; pp. $173-$ 180.
[28] Onibokun, A. G., Adedipe, N. O. and Sridlier, M. K. C. 2000 Affordable Technology and Strategy for Waste Management: African Lessons and Experiences. Center for African Settlement Studies and Development CASSAD Series, No. 13 , pp. $1-134$.

[29] Rochman CM (2013) Plastics and Priority Pollutants: A Multiple Stressor in Aquatic Habitats. Environmental Science \& Technology. 47 (6): 2439 - 2440.

[30] Rochman CM, Hoh E,Kurobe T, Teh SW (2013) Ingested Plastic Transfers hazardous Chemicals of Fishes and induces Hepatic Stress. Nature (494): 169 - 171.

[31] Roy, M., Rollin, A. L. and Schreiber, H. P. 2004: Value Recovery from Polymer Wastes by Pyrolysis. Polymer Engineering \& Science. Vol. 18, Issue 9; pp. 721 - 727, (July).

[32] Saunder, K. J. 1998: Organic Polymer Chemistry: An Introduction to the Organic Chemistry of Adhesives, Fibers, Paints, Plastics, and Rubbers. London: Chapman and Hall. ( $2^{\text {nd }}$ Edition); pp. 6 - 11

[33] Shinsato, A. L. 2005: Increasing the Accountability of Transnational Corporation for Environmental Harms: The Petroleum Industry in Nigeria. Northern Journal of International Human Rights. Vol. 4, No. 1; pp.186 - 209.

[34] UNCED (1992): The Rio Declaration on Environment and Development (1992) - The United Nations Conference on Environment and Development, and its evolution to 2013. Geneva: United Nations

[35] United Nations (2012): The future we want. Geneva: United Nations.

[36] Walling, E., Walston, A., Warren, E., Warshay, B. and Wilhelm, E. 2004: Municipal Solid Waste Management in Developing Countries, Nigeria, a Case Study. Group 9, NTRES, 314

[37] Weber, R. Gaius, C. Tysklind, M. Johnston, P. Forter, M. Hollerti, H. Heinisch, E. Holoubeck, I. Lloyd-Smith, M. Masunaga, S. Moccarelli, P. Santillo, D. Seike, N. Symons, R. Torres, J. P. Verta, M. Varbelow, G. Vijqen, J. Watson, A. Costner, P. Woelz, J. and Zenneqq, M. 2008: Dioxn- and POP- contaminated Sites - Contemporary and Future Relevance and Challenges: Overview and Background, Aims and Scope of the Series. Environmental Science Pollution Research International. Vol. 15; No. 5, pp. $363-$ 93, (July)

[38] William, J. F. 2002. There Really Is a Santa Claus: The History of St. Nicholas \& Christmas Holiday Traditions, Amerisearch (3) 3 pp. $234-242$.

[39] Zaini, S. 2011: Municipal Solid Waste Management in Malaysia. Journal of Applied Sciences in Environmental Sanitation. Vol.6; No. 1 pp. $29-38$. 